\title{
LOCAL SELF-GOVERNMENT
}

DOI https://doi.org/10.30525/978-9934-26-045-2-34

\section{ДІЯЛЬНІСТЬ ЗЕМСЬКИХ ТА МІСЬКИХ ОРГАНІВ МІСЦЕВОГО САМОВРЯДУВАННЯ У ПІВНІЧНОПРИАЗОВСЬКОМУ РЕГІОНІ: РЕТРОСПЕКТИВНИЙ АСПЕКТ}

\author{
Шумілова І. Ф. \\ доктор педагогічних наук, \\ доиент кафедри менеджменту та адміністрування \\ Бердянського державного педагогічного університету
}

Артеменко Д. С.

студент магістратури спеціальності 011 Освітні, педагогічні науки освітньо-професійної програми «Управління закладом освіти» Бердянського державного педагогічного університету

Тараненко І. Ю.

студент магістратури специіальності 011 Освітні, педагогічні науки освітньо-професійної програми «Управління закладом освіти» Бердянського державного педагогічного університету м. Бердянськ, Запорізька область, Україна

Згідно 3 енциклопедією освіти, земство це орган місцевого самоврядування в дореволюційній Росії. Земства сформувалися відповідно до «Положення про земські установи», затвердженого царським урядом 01.01.1864 р. Вибори до земських управ проводились на основі високого майнового цензу й куріальної структури обрання гласних, що забезпечувало перевагу дворянству. Проте до них обиралась і значна частина прогресивно налаштованої інтелігенції (агрономи, вчителі, лікарі, статистики тощо). До функцій земств входило розв'язання місцевих господарських справ у губерніях і повітах), благоустрій територій, будівництво доріг, шкіл, лікарень тощо)...[3, с. 319].

Земство - орган місцевого самоврядування, створений згідно 3 адміністративною земською реформою 1864 р. у більшості губерній Російської імперії. Юридично земства були загальностановими 146 
виборними органами 3 розпорядчими (земські зібрання) та виконавчими (земські управи) функціями. Контролювалися міністерством внутрішніх справ та губернаторами, які мали право скасування земських рішень. Вибори до земств здійснювалися по куріях (розрядах) відповідно до станової, національної належності, віросповідання чи майнового цензу, що надавало перевагу дворянству. Права недворянських станів та представництва у земств ще більше обмежувалися законом від 12 червня 1894 р. Земства займалися питаннями місцевого господарства, медицини, частково народної освіти, ветеринарної служби, місцевого зв'язку, страхування, статистики тощо. В Україні земства створені в 1911 р., скасовані у 1918 р. [2, с. 259].

Земська реформа 1864 р. - одна 3 реформ 60-70 pp. ХІХ ст. в Російській імперії, у ході якої російське самодержавство прагнуло залучити до управління місцевими справами, до розвитку місцевого господарства підприємницькі прошарки дворянства, селянства, міських жителів. Реалізація земської реформи 1864 р. («Положення про губернські й повітові земські установи» від 1 січня 1864 р.) привела до створення в губерніях і повітах системи представницьких органів повітові й губернські земські збори. На Правобережній Україні, де сильні були пропольські настрої, земську реформу 1864 р. впроваджено лише у 1911 р. у трьох правобережних губерніях - Київській, Волинській та Подільській [2, 259-260].

Історія питання свідчить, що 1 січня 1864 року у Російській Імперії запроваджувалася нова система державного управління на місцях - земські та міські органи самоврядування. Їх поява була обумовлена серйозними об'єктивними причинами. Скасування кріпацтва вимагало принципово нової організації усіх служб місцевого управління. Земські установи запроваджувалися як поступка дворянству, але об'єктивно сприяли прискоренню буржуазного розвитку країни. Самодержавство максимально обмежило функції земських закладів, підпорядкувало їх адміністративній та фінансовій опіці з боку державних інститутів на місцях і в центрі [6, с. 1-78].

Земські заклади запроваджувалися не скрізь, а лише у 34 губерніях Свропейської Росії, серед них і у 9 українських: Волинській, Катеринославській, Київській, Подільській, Полтавській, Таврійській, Харківській, Херсонській та Чернігівській. У Полтавській, Харківській та Чернігівській губерніях земські установи було введено в 1865 р., а в Катеринославській та Таврійській - у 1866 р.

Діяльність земств суворо регламентувалося господарськими справами: будівництвом, місцевими дорогами, школами, лікарнями, 
притулками, організацією опікування, благодійністю, харчуванням, земською статистикою, ветеринарним контролем тощо.

Земські установи мали чітко зафіксовану у законі структуру: розпорядчі органи - губернські та повітові земські зібрання, а виконавчі - губернські та повітові земські управи. Губернські зібрання скликалися один раз на рік на термін не більше 20 днів та складалися із гласних, обраних на основі майнового цензу та куріальної системи. Перша та друга курії не мали станового характеру, тоді як третя селянська, була становою. Кількість губернських гласних не перевищувала 50 осіб. Повітові земські зібрання були меншими, скликалися кожного року на термін до 10 днів. Земська управа обиралася на три роки. Вона складалася з кількох осіб, які вирішували питання земського господарства та запрошення на службу вчителів, лікарів, агрономів, статистів та інших службовців [4, с. 30-31].

У першому проекті «Положения о губернских и уездных земских учреждениях», складеному Міністерством внутрішніх справ та поданому 1863 року до Державної Ради, про участь земства у справі народної освіти і не згадувалося. Проте в остаточній редакції затвердженого «Положения» земству дозволялося піклування про народну освіту «переважно у господарському відношенні» (п.VII, ст.2). При цьому земські витрати на школу було віднесено до розряду «необов'язкових». Сдиною можливістю земств впливати на навчальне життя - надання їм права заміщати два місця в училищних радах, які існували до березня 1917 року [7, с. 1-11].

У перші десятиліття існування органів самоврядування, губернські земства відігравали незначну роль у розвитку народної освіти. Попечителями освіти були повітові земства, які зіткнулися 3 необхідністю спочатку обмежитися скромним завданням переконувати селян будувати школи та налагоджувати збір коштів для цього. Також вони виділяли кошти на платню вчителям і у 90-ті роки XIX століття повністю взяли ії на свій баланс і значно підвищили. У цей час повітові земства починають брати участь у постачанні шкіл навчальним приладдям, виділяють кошти на опалення, освітлення, обслугу тощо. За даними Б. Веселовського, у кінці $70-\mathrm{x}$ років $\mathrm{XX}$ століття частка сільських громад у витратах на народні школи становила 45\%, наприкінці $80-\mathrm{x}-30 \%$, а у $1900-5 \%$ [1, с. 9].

Активізація діяльності земств у галузі народної освіти викликала реакційні дії уряду, спрямовані на обмеження впливу губернських та повітових земств на початкові училища. 1869 року було затверджено Інститут Інспекторів народних училищ, утворювалися зразкові 
міністерські школи. 1874 року було затверджено нове «Положение о начальных училищах», яке діяло до 1917. Воно поставило народну школу у безпосереднє підпорядкування місцевим органам Міністерства народної освіти - дирекціям народних училищ. Проте училищні ради не збиралися роками, інспектор народних училищ завідував одразу кількома повітами і не мав можливості здійснювати контроль. Фактичними керівниками адміністративних шкільних справ та навчального процесу залишалися земські управи, зібрання та представники земств в училищних радах [1, с. 49].

У «Положении о губернских и уездных земских управах» від 1890 року зазначалось, що у галузі освіти до їх компетенції належить «піклування про розвиток засобів народної освіти і встановлена законом участь у завідуванні утримуваними за рахунок земств школами та іншими навчальними закладами» $[8$, с. 25]. У цьому документі, який вважався головним для земств, їх права і обов'язки не були чітко визначені. Пізніше вони конкретизувались у багатьох законодавчих актах, інструкціях та положеннях. Держава залишала за собою право постійно коригувати і спрямовувати земську діяльність у своїх інтеpecax, ставлячи ii в залежність від певних політичних чи економічних умов. Як свідчить вивчений досвід земств, спостерігалась тенденція не допускати розширення прав місцевого самоврядування, зберігати контроль держави над народною освітою. Така політика влади виявлялась у постійних відхиленнях земських пропозицій та клопотань у галузі освіти, циркулярних обмеженнях просвітницьких заходів земств.

12 червня 1900 року було прийнято закон про фіксацію зростання земського оподаткування, згідно 3 яким земствам заборонялося розширювати витрати на народну освіту не більше ніж на $3 \%$ на рік. Особливо несприятливим для земств був період 1910 - 1914 років, коли Міністром освіти був Л.Кассо, бо в цей час значно посилився інститут шкільної інспекції, учителі вже не вважалися земськими службовцями, через що їх звільнення з посад чи переміщення було виведено 3 компетенції земств і стало прерогативою шкільної інспекції $[9,115]$. Разом з урядовими обмеженнями земської освітньої діяльності посилилось втручання у їхню роботу місцевої адміністрації. Губернатори часто висловлювали незгоду 3 рішенням земських зборів $\mathrm{i}$ не затверджували їх, що робило ці рішення нечинними.

Така політика уряду засвідчувала, що порівняно 3 повнотою влади, яку за законом мали інспектори, училищні ради, губернатори i навіть предводитель дворянства, земства зовсім не мали підтримки 3 
боку держави. Протягом усього періоду своєї діяльності земства боролися з урядом. Про це свідчать численні земські клопотання щодо розширення прав земств в управлінні початковими народними школами [5, с. 251-257].

А головний висновок полягає в тому, що в основу земської діяльності в північнопризовському поліетнічному освітньому просторі було закладено тезу про необхідність побудови нової початкової школи на загальнолюдських цінностях та пристосування іiі до особливостей різних національностей та умов їх буття.

Отже, поява земської школи у північноприазовському регіоні детермінувалась значним комплексом об'єктивних та суб'єктивних чинників: соціальних, економічних, історичних, географічних, національних, загальнокультурних, персоналістичних та інших. До того ж Північне Приазов'я являло собою унікальне етнокультурне середовище, що обумовлювало тенденції створення початкової школи нового типу, яка б була спрямована на забезпечення культурних $\mathrm{i}$ освітніх інтересів українців, росіян, болгар, греків, німців та інших етнічних груп регіону.

\section{Література:}

1. Веселовський Б.Б. Земство и земская реформа. - П.г., тип. Попова, 1918. - 40 с.

2. Енциклопедичний словник з державного управління / уклад. : Ю. П. Сурмін, В. Д. Бакуменко, А. М. Михненко та ін. ; за ред. Ю. В. Ковбасюка, В. П. Трощинського, Ю. П. Сурміна. - К. : НАДУ, 2010. -820 c.

3. Енциклопедія освіти / Акад. пед. наук України ; головний ред. В. Г. Кремень. - К. : Юрінком Інтер, 2008. - 1040 с.

4. Краткая энциклопедия земского дела. К., 1914. 124 с.

5. Пирумова Н.М. Альтернатива (Об истории появления земств в России, их дела и возможности) // Родина. - 1992. - № 8-9. - С. 26-29

6. Полное собрание законов Российской империи. - Изд. III. СПб., 1900. - Т. XII. - 1867 c.

7. Положение о губернских и уездных земских учреждениях. 2ПС3. - Т. ХХХІХ. Отд. 1. - СПб., 1864; 1867. - № 40457

8. Положение о начальных народных училищах. - СПб., 1875. $-325 \mathrm{c}$.

9. Положение о губернских и уездных земских учреждениях. СПб., 1911. - $162 \mathrm{c}$. 